\title{
THE STRUCTURE OF SEPTAL NECTARIES AND NECTAR PRESENTATION IN THE FLOWERS OF Allium aflatunense B. FEDTSCH.
}

\author{
${ }^{1}$ Beata Żuraw, Elżbieta Weryszko-Chmielewska \\ ${ }^{2}$ Halina Laskowska, Elżbieta Pogroszewska
}

\author{
${ }^{1}$ Department of Botany, University of Life Sciences, Akademicka 15, 20-950 Lublin, Poland \\ e-mail: beata.zuraw@up.lublin.pl \\ ${ }^{2}$ Institute of Ornamental Plants and Landscape Architecture, University of Life Sciences, \\ Leszczyńskiego 58, 20-068 Lublin, Poland \\ e-mail: halina.laskowska@up.lublin.pl
}

Received: 12.09.2009

\section{Abstract}

The location and structure of the septal nectaries in the flowers of Allium aflatunense B. Fedtsch. were studied. Light and scanning electron microscopy were used for examination. It has been shown that the septal nectaries are located in the lower part of the ovary and in the gynophore on which the ovary is borne. Nectar is secreted through the single-layered epidermis surrounding three nectary slits and nectar release occurs through three openings located at the base of the gynophore, which are the outlets of the ducts connected to the nectary slits. The expanded and fused bases of the stamen filaments and the tepals participate in secondary nectar presentation. In the flowers of Allium aflatunense, numerous purple elements: tepals, filaments, style and pedicle, perform the role of a colour attractant. On the intensely green ovary, there occur glistening conical outgrowths of epidermal cells, which may also function as signal attractants.

Key words: Allium aflatunense, flowers, ecological features, micromorphology, nectaries, anatomy, nectar

\section{INTRODUCTION}

The genus Allium L. (Alliaceae) includes 700 species and subspecies native to the Northern Hemisphere (Fritsch and Friesen, 2002). Many garlic varieties originating from southern Europe and Asia have found application as border plants or cut ornamental plants (Maurizio and Grafl, 1969). These plants are characterized by high frost resistance and low fertilization requirements ( $\mathrm{Krzy} \mathrm{m}$ iń s k a, 2003).

Most ornamental species and varieties of garlic offered for sale are derived from species of the subgenus Melanocrommyum, which contain a small amount of cysteine sulfoxide being a source of volatile sulphur components and inactive cysteine, and therefore they are almost odourless (Dobozet et al. 1992; De Hertogh and Zi m mer, 1993).

Inflorescence stems of Allium aflatunense B. Fedtsch., originating from the abovementioned subgenus, reach $120 \mathrm{~cm}$. The inflorescence with a diameter of $10-12 \mathrm{~cm}$ is composed of about 200 flowers. The tepals are initially violet, then purple. The flowering period is from May to June. This species is grown on a wide scale in soil and in greenhouses for cut flowers. The most common cultivar Purple Sensation produces inflorescences with a length of $70-90 \mathrm{~cm}$, bearing purple-violet flowers (B i j 1, 1995; Frie s e n et al. 1997).

The flower of Allium is composed of a 6-tepalled perianth, six stamens forming two whorls, fused at the base with the perianth, and a three-chambered superior pistil. The stamens of the inner whorl have filaments which are expanded double-sidedly at the base. Three septal nectaries are found inside the ovary ( $\mathrm{Mau}$ rizio and Graf1, 1969). In pollination ecology, the flowers of Allium are classified, in morphological terms, as bowl-shaped flowers with hidden nectaries (S z afer and Wojtusiakowa, 1969; Kugler, 1970).

Septal nectaries, included in the gynopleural type, are found in plants from several families belonging to the class of monocotyledons. They are distinguished, among others, in Alliaceae, Asparagaceae, Asphodelaceae and Iridaceae (W e b e r ling, 1992; Voge 1, 1998; S mets et al. 2000; WeryszkoChmielewska et al. 2006; Bernardello, 2007).

The aim of the present study was to determine the location and size of the septal nectaries in the flowers of 
Allium aflatunense and to estimate the rate of nectar production in plants of this species. Furthermore, the ecological features of its flowers, contributing to their attractiveness for insects, were analysed.

\section{MATERIALS AND METHODS}

The study related to the anatomy and micromorphology of different floral parts of Allium aflatunense $c v$. Purple Sensation. The plants came from a collection of the Department of Ornamental Plants of the University of Life Sciences in Lublin.

Light microscopy observations were performed based on manually cut sections from fresh plant material and from plant material fixed in $70 \%$ ethanol. Cross sections were made at different places of the ovary and the gynophore in order to locate the septal nectaries.

The material for scaning electron microscopy examination was fixed in $4 \%$ glutaraldehyd in $0.1 \mathrm{M}$ phosphate buffer for 4 hours at room temperature. The samples were dehydrated in ethanol and acetone series. Then, they were critical-point dried in liquid $\mathrm{CO}_{2}$ and coated with gold. Observations were performed in a BS-340 Tesla microscope.

The nectar production rate was investigated in 2009 using the pipette method described by J a błoński (2003). For this purpose, at the full bloom stage, 10 buds in each of 4 inflorescences were marked and the whole buds were isolated using tulle fabric in order to prevent insect access. The marked flowers were picked on the date of maximum nectar accumulation in them (4th day of flowering) and taken to the laboratory. The nectar was collected with micropipettes, four nectar samples from each of the 10 flowers. After the determination of nectar weight, the concentration of sugars contained in the nectar was determined using a refractometer.

\section{RESULTS}

Not only the perianth and androecium are the attractant of the flowers of Allium aflatunense cv. Purple Sensation, but also the intensely coloured styles and pedicles (Figs 1-6). Already at full bud burst, the abovementioned elements have a purple colour, contrasting with the intensely green ovary (Figs 2, 4, 6), whose colour comes from the layer of subepidermal parenchyma containing numerous chloroplasts (Figs $7,8)$.

The tepals are supplied by one centrally located vascular bundle, terminated with spiral tracheids, which does not reach the apex of the tepals (Figs 9, 12). Few stomata are only found in the adaxial epidermis (Figs 10,13). They are arranged in rows in the vicinity of the vascular bundle, most frequently singly and sometimes in pairs (Figs 14, 15). In the layer of cuticle covering the elongated epidermal cells of the perianth segments, densely distributed striae were observed with a wavy or parallel arrangement. The guard cells had well-developed outer cuticular ledges (Figs $14,15)$. In the vacuoles of some epidermal cells, calcium oxalate crystals were observed in the form of styloids (Fig. 11).

The lower portions of the filaments of the inner and outer whorl of stamens were strongly expanded (Figs 3, 5, 17, 18, 19). The cells of the epidermis covering the anthers had an isodiametric shape (Fig. 16), whereas those occurring on the filaments were strongly elongated (Fig. 21). The expansions in the lower part of the stamen filaments of both whorls were fused together (Figs 3, 5) and they were slightly concave (Figs 17, 19). This surface was in contact with the secretion flowing from the septal nectaries. In these regions, the epidermal cells were covered by an irregularly striated cuticle (Figs 20,22). The striations of the cuticle could facilitate the retention of nectar.

The pistil grew from the receptacle borne on a small gynophore, forming a distinct stalk between the base of the androecium and the ovary (Fig. 4). The ovary was covered by glistening epidermal cells characterized by a strongly protruding outer wall, and frequently by a conical shape (Figs 4, 23-26). Their surface was also covered by a distinct layer of cuticle with strongly marked striae. The epidermal cells with a height of approx. $160 \mu \mathrm{m}$ exceeded many times, in terms of their size, the parenchyma cells located beneath them (Fig. 26). The outer wall of the epidermal cells was distinguished by a significant thickness (Figs $25,26)$.

The septal nectaries formed three sacs situated in the septa of the lower part of the ovary and within the gynophore (Figs 27-31). Based on the analysis of the cross sections of the ovary, it has been found that the upper boundary of the nectaries is situated at half height of the ovary (Figs 27, 28, 32), and in its lower regions and within the gynophore the nectariferous tissue is well developed and occupies a large area of the cross section (Figs 29-31). The single-layered palisade secretory epidermis of the nectary (secretory epithelium) (Figs 35,39 ) surrounds a narrow space, extending along a broken line, in which nectar accumulates (Figs 3335 ). When viewed in cross section, the radial length of each of the three parts of the nectary ranged between $260 \mu \mathrm{m}$ and $470 \mu \mathrm{m}$, with the highest values recorded within the ovary and the lowest values in the gynophore. The width dimensions of the nectary had opposite values. In the lower region of the gynophore, the secretory cavity together with the secretory tissue was the widest $(175 \mu \mathrm{m})$, and within the ovary its 

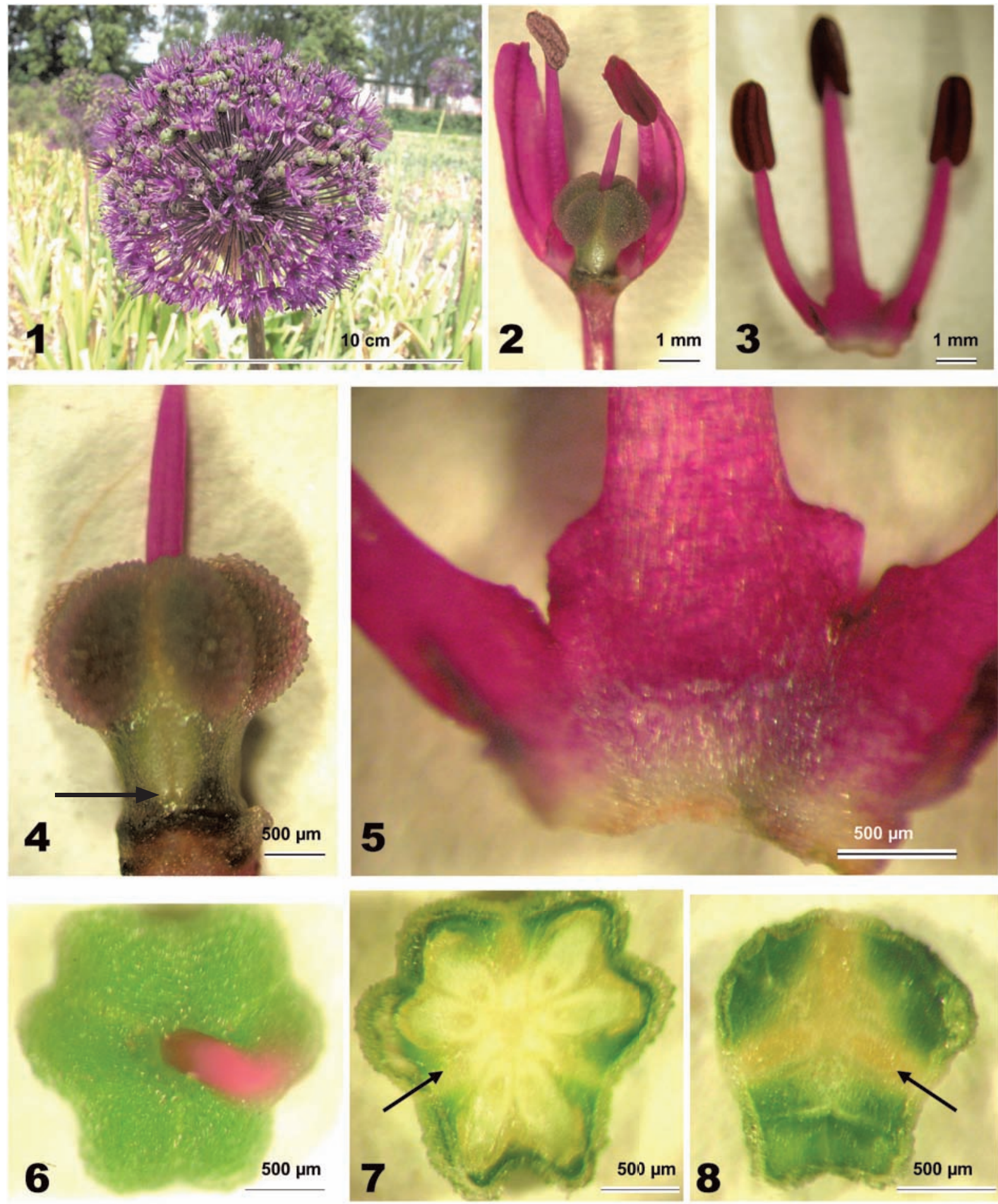

Figs 1-8. Inflorescence and floral parts of Allium aflatunense.

2 - Pistil with stamens and tepals.

3 - Part of the androecium with fused bases of the filaments.

4 - Pistil with the gynophore in which the outlets of the nectary are located (arrow).

5 - Expanded basal parts of the stamen filaments.

$6,7,8,-$ Successive cross-section parts, from top down, of the pistil's ovary with the visible location of the nectaries (arrows). 

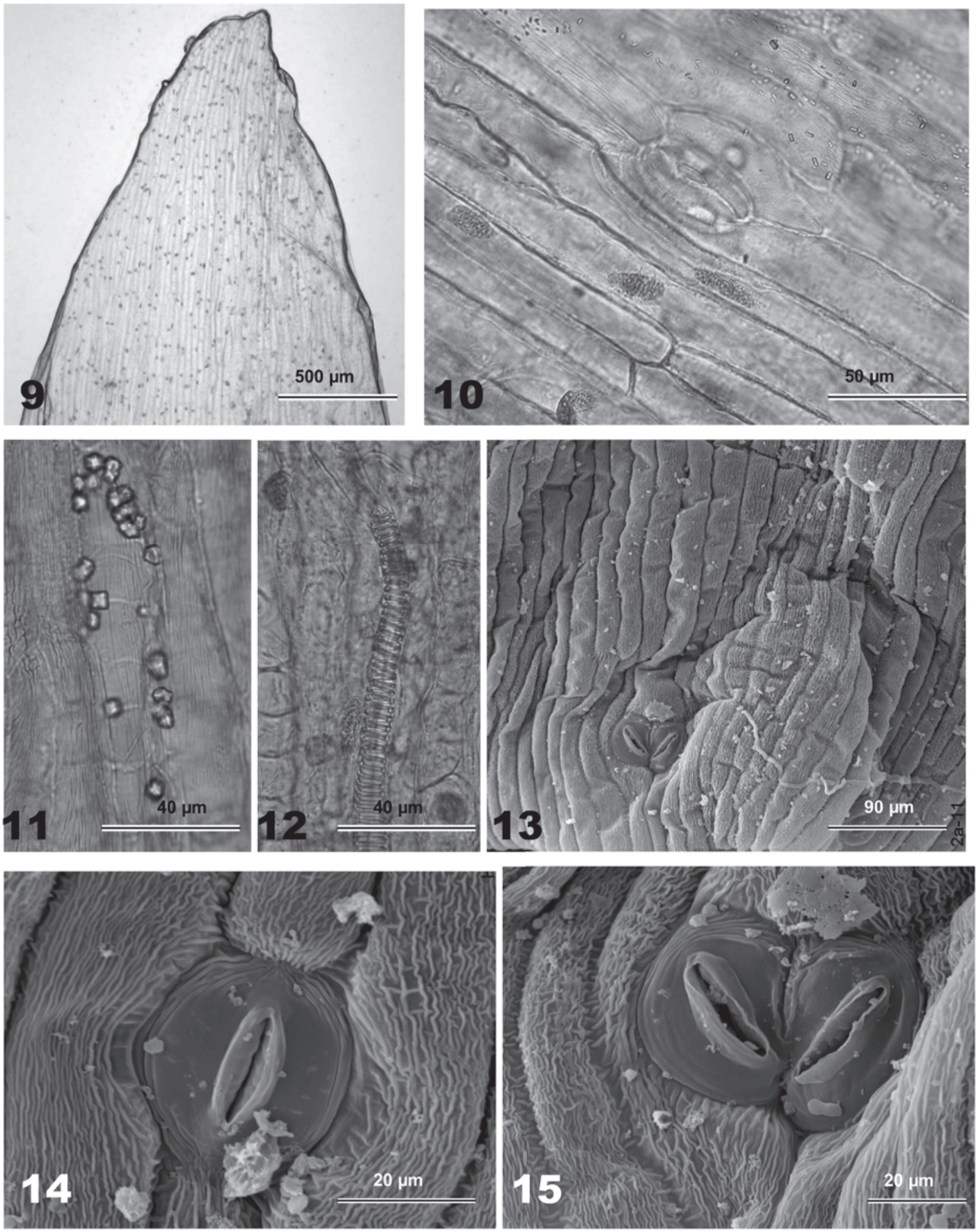

Figs 9-15. Parts of tepals of Allium aflatunense.

9 - Apical part of the tepal. 10 - Stoma in the adaxial epidermis. 11 - Calcium oxalate crystals in epidermal cells. 12 - Apical vessels in the vascular bundle. 13 - Folded adaxial surface of the apical part of the tepal. 14, 15 - Stomata in the adaxial epidermis with well-developed outer cuticular ledges. 

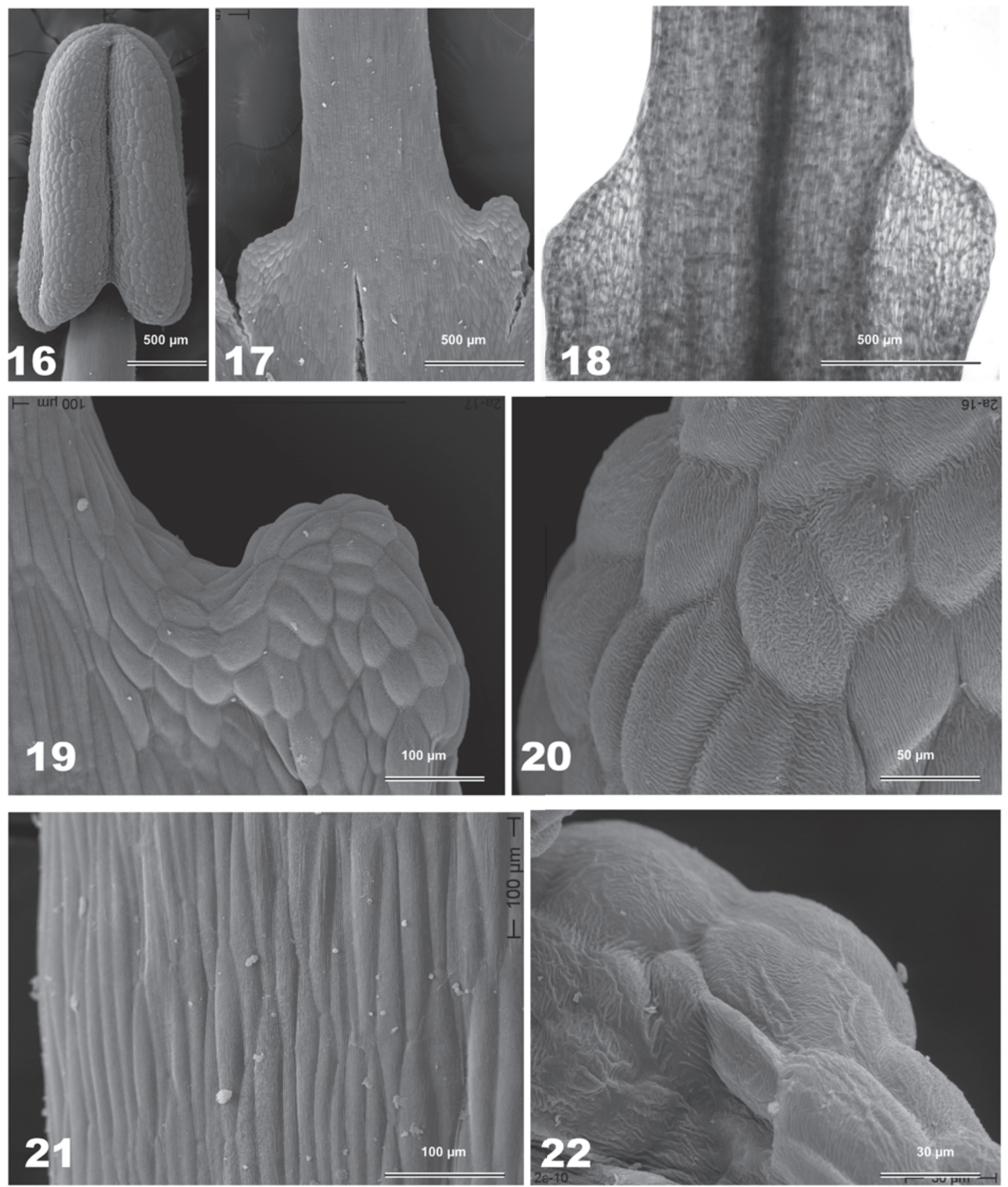

Figs 16-22. Parts of stamens of Allium aflatunense.

16 - Adaxial surface of thecae (SEM).

17 - Lower, expanded part of the stamen filament; visible fusion with the adjacent filaments at the bottom (SEM).

18 - Lower part of the stamen filament (LM).

19 - Portion of the expanded part of the filament (SEM).

20 - Surface of the epidermis of the filament with the anisotropic arrangement of cuticular striae (SEM).

21 - Surface of the upper part of the stamen filament (SEM).

22 - Depressed adaxial part of the expansion of the filament (SEM). 

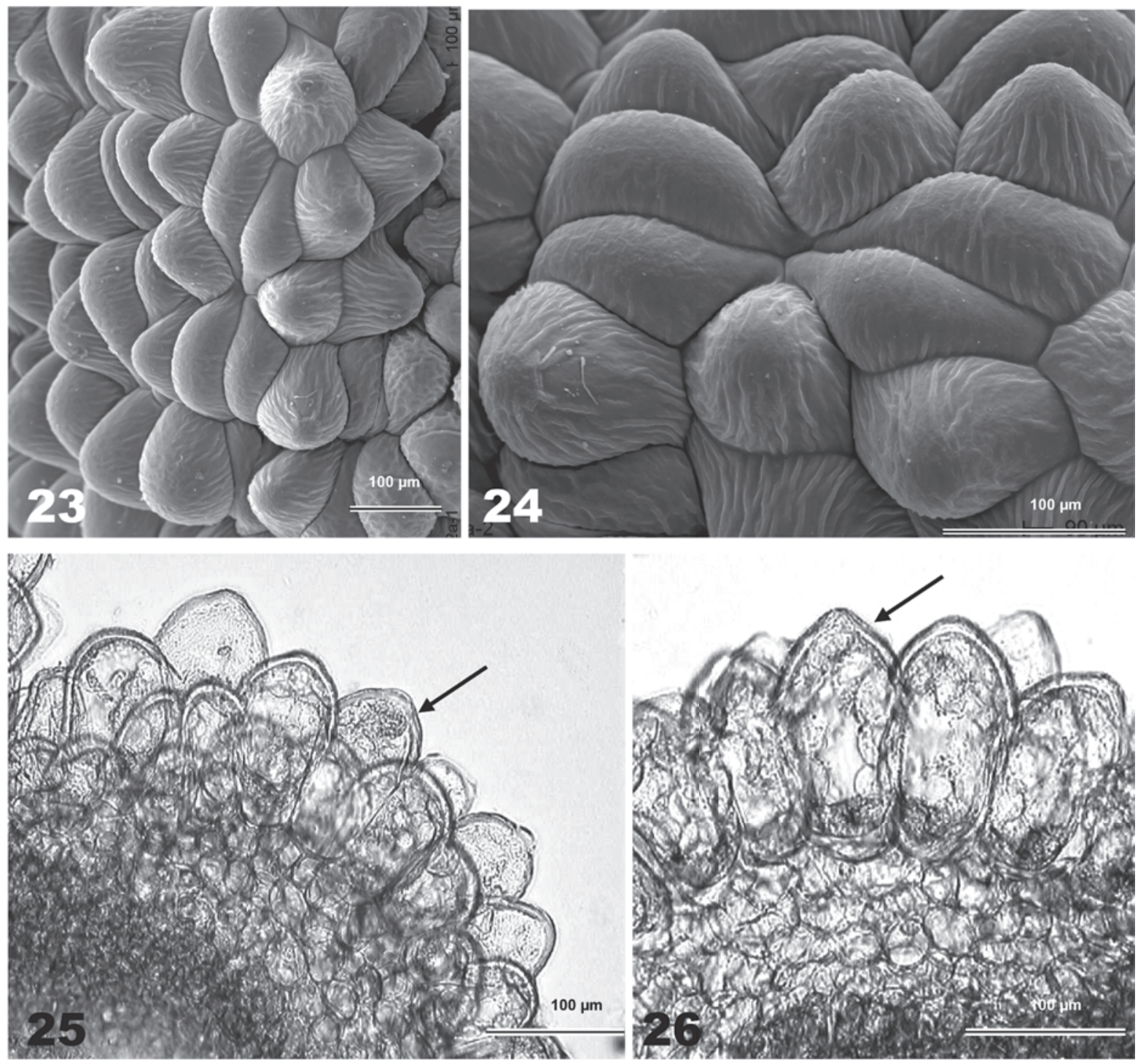

Figs 23-26. Parts of the ovary of Allium aflatunense.

23, 24 - Conical epidermal cells are covered by a striated cuticle (SEM).

25, 26 - Cross section of the outer part of the ovary wall (LM); visible elongated epidermal cells with a thick outer cell wall. 

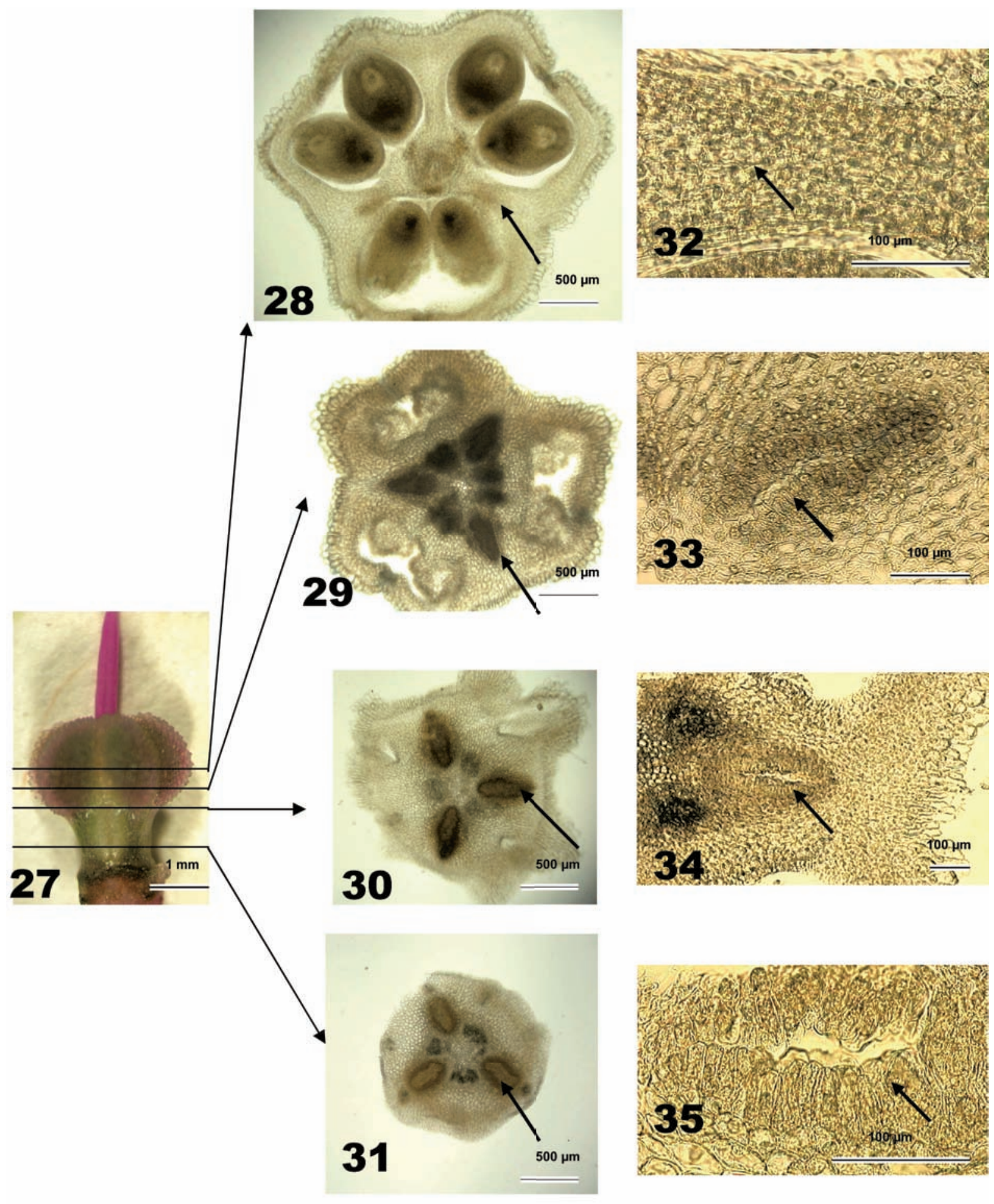

Figs 27-35. Cross sections of the lower part of the ovary and gynophore showing the location of the septal nectaries of Allium aflatunense.

27 - Location of cross sections in the ovary and gynophore. 28 - Cross section at half height of the ovary in which the upper range of the nectaries is visible (arrow). 29 - Septal nectaries (arrow) in the lower part of the ovary. 30 - Septal nectaries (arrow) at the boundary of the ovary and gynophore. 31 - Septal nectaries (arrow) in the gynophore. 32 - Part of the ovary septum with a poorly visible upper boundary of the nectary (arrow). 33-35 - Septal nectaries from different parts of the ovary and gynophore with varying arrangements of the septal slit. 


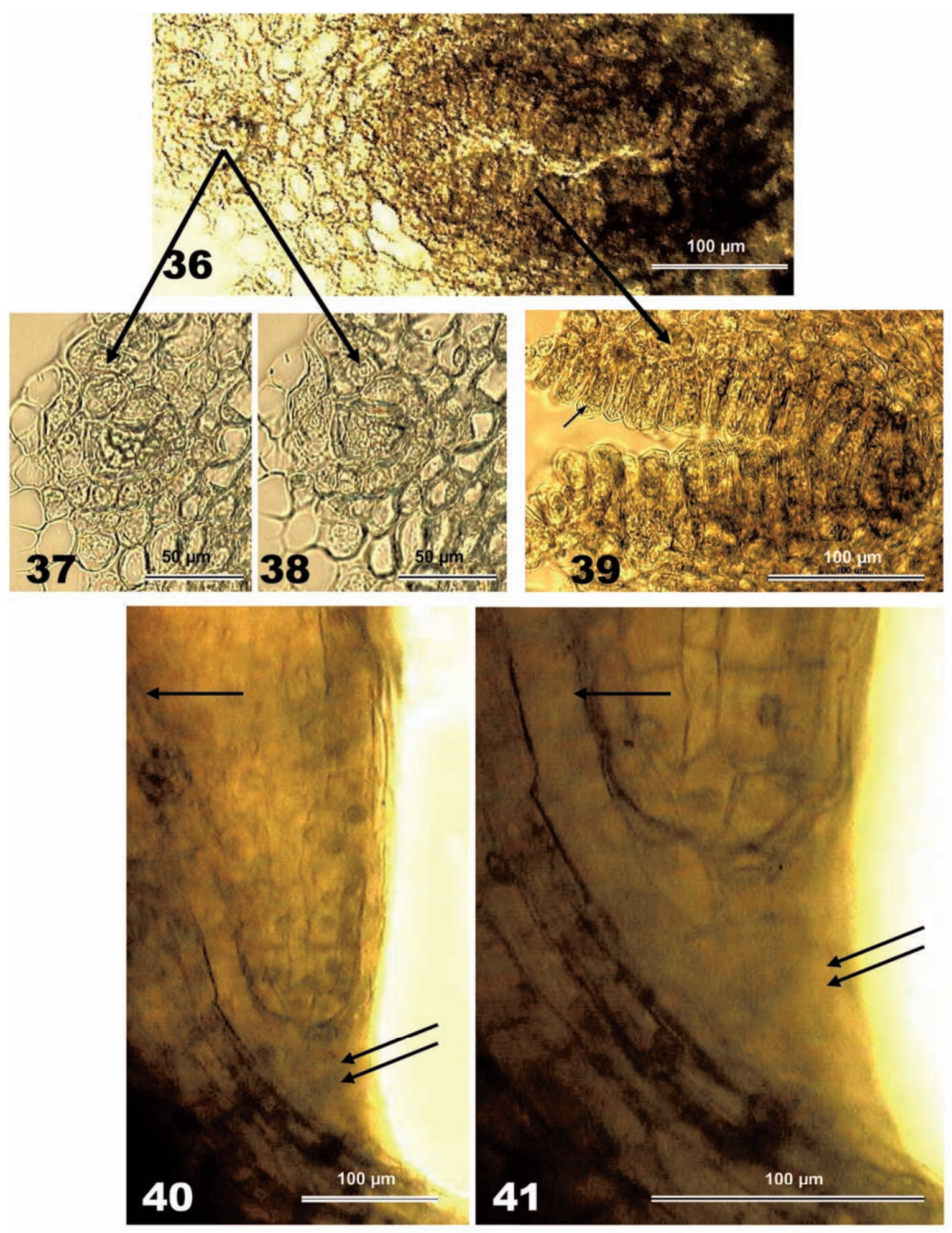

Figs 36-41. Cross-section parts of the gynophore with the visible nectary and the duct transporting nectar.

36 - Cross-section part with the nectary and the duct located outside it. 37, 38 - Ducts transporting nectar viewed in cross section, surrounded by the secretory epithelium with secretion visible in the secretion pore. 39 - Cross-section part of the nectary with one layer of palisade cells of the secretory epithelium (arrow). 40-41 - Lower part of the duct (arrow) releasing nectar through an opening (double arrows) at the base of the gynophore. 
width was almost twice smaller $(95 \mu \mathrm{m})$. Each part of the nectary was connected, in the upper region of the gynophore, to a duct running at a certain distance from the septal secretory tissue (Fig. 36). The duct was surrounded by the secretory parenchyma cells. Secretion was observed at some places of the ducet (Figs 37, 38). The outlet of each of the three ducts was located in the lower part of the gynophore (Figs 4, 40, 41). The measurements show that the duct diameter is within a range of 17-48 $\mu \mathrm{m}$, whereas its expansion at the outlet reaches a height of approx. $100 \mu \mathrm{m}$.

The nectar released accumulates in spoonshaped depressions of the expanded and fused together filaments, forming a kind of ring retaining the nectar, from whence it gets to the basal parts of the tepals. Therefore, secondary nectar presentation in this taxon is associated with the androecium and the tepals.

On the peak date of nectar secretion, which fell on the fourth day of flower life, the garlic flowers had their stamens with pollen released and an elongated style. Nectar secretion was observed within 4 days from the opening of the tepals, which corresponded to flower lifetime in this species in field growing conditions. After the end of flowering and of the nectar secretion process, the tepals lost turgor, changed their colour, bent downwards and dried up.

From the 10 flowers of the investigated plants, an average of $4.57 \mathrm{mg}$ of nectar was obtained with high sugar concentration (on the average $75.1 \%$ ), reaching up to $76.4 \%$. The weight of sugars identified in the nectar of 10 flowers was $3.42 \mathrm{mg}$, on the average. The estimated weight of sugars from one inflorescence numbering 200 flowers was approx. $68.4 \mathrm{mg}$.

\section{DISCUSSION}

An important trait in pollination ecology of $\mathrm{Al}$ lium aflatunense is the intense purple colour of many floral elements: perianth, stamen filaments, style and pedicle. Flower colours are considered to be signal attractants for pollinators (B a n s zak, 1987). The models (formulas) for tepal colour and nectar guides in flowers accord with the physiological characteristics of the senses of relevant pollinators ( $\mathrm{D}$ a f $\mathrm{n} \mathrm{i}$ and $\mathrm{K} \mathrm{e} \mathrm{v} \mathrm{a} \mathrm{n} \mathrm{1996).} \mathrm{The} \mathrm{observations} \mathrm{of} \dot{Z} u \mathrm{r}$ a w (2007) show that the flowers of Allium aflatunense were most frequently visited by the honey bee and solitary bees. Moreover, bumblebees, butterflies and dipterans were also noted in them.

The stamen filaments expanded in their lower part are a special adaptation facilitating the retention of abundantly secreted nectar in the bowl-shaped flowers, which is also described in different Allium species by M a u ri zi o and G r a fl (1969). In A. aflatunense in question, the expanded filaments of the inner whorl of stamens are located opposite to the openings in the lower part of the gynophore from which nectar flows. In literature the outgrowths or expansions of filaments are treated as transformed stipules or basal stamen appendages (W e b e r ling, 1992).

Septal nectaries are the most frequently encountered type of nectaries in monocotyledons. Their characteristic feature is that nectar production and release occur at different sites of the ovary ( $\mathrm{S} \mathrm{mets}$ et al. 2000). Nectar is produced and secreted in the layers of the nectary epithelium, whereas nectar release in different plant species occurs through the outlets located at different levels of the ovary. In Allium aflatunense we found that there were 3 outlets in the lower part of the gynophore associated with nectar release. In literature we have not hitherto found any data about such a location of the septal nectaries and their outlet. But Maurizio and Graf 1 (1969) report that the openings releasing nectar are located in different Allium species at half height of the ovary. $\dot{Z}$ u r a w (2008) also observed the outlets of the septal nectaries at half height of the ovary in A. flavum and A. sphaerocephalon, but in several other Allium species - in the basal part of the ovary.

In Asphodelus aestivus the openings releasing nectar are also located at half height of the ovary (Weryszko-Chmielewska et al. 2006). In many other species, the outlets of the septal nectaries are located in the upper part of the ovary, at the base of the style: in Gladiolus and Haworthia (W e b e r 1 in g, 1992), Haemanthus and Yucca (S met s et al. 2000), Acidanthera (Weryszko-Chmielew ska et al. 2003) as well as in Aloë (N e p i et al. 2006).

Because in the case of all septal nectaries the site of nectar production and the site of its presentation have different locations, in accordance with a suggestion made by $\mathrm{Pac}$ in i et al. (2003), it can be stated that secondary nectar presentation occurs in the flowers of plant species producing this type of nectary.

The weight of nectar produced by a single A. aflatunense flower was $0.46 \mathrm{mg}$. This value falls within the lower limits of the nectar production rate for ornamental species of Allium, which produced from 0.2 up to $1.2 \mathrm{mg}$ of nectar (S z k la n o w s k a, 1982). But the sugar content in the nectar of A. aflatunense, as determined in our study, was higher than the nectar concentrations previously obtained by the abovementioned author for 10 other ornamental species of the genus Allium (48\% - 66\%).

\section{CONCLUSIONS}

1. The septal nectaries are located in A. aflatunense in the lower part of the ovary and in the gynophore. Nectar release occurs through the outlets located in the lower part of the gynophore. 
2. In A. aflatunense, the stamens and tepals take part in secondary nectar presentation.

3. The weight of nectar produced by a single flower of A. aflatunense falls within the lower limits of nectar released by other ornamental garlic species.

4. The nectar of the abovementioned species is characterized by very high sugar concentration.

\section{REFERENCES}

B a n a s z a k J., 1987. Pszczoły i zapylanie roślin. Państwowe Wydawnictwo Rolnicze i Leśne, Poznań.

Bernarde1lo G., 2007. A systematic survey of floral nectaries. [In:] Nicolson S. W., Nepi M., Pacini E. (eds.). Nectaries and nectar. Springer, Dordrecht.

Bij1 J. R., 1995. Allium - flowering onions. Herbertia, 50: 8894.

Dafni A., Kevan P. G., 1996. Floral symmetry and nectar guides: ontogenetic constraints from floral development, colour pattern rules and functional significance. Bot. Jour. Linn. Society, 120: 371-377.

De Hertogh A. A., Zi m mer K., 1993. Allium - ornamental species. W: De Hertogh A. A., Le Nard M. (red.). Physiology of Flower Bulbs. Elsevier, Amsterdam: 187-200.

Dubozet J. G., Arisumi K. I., Etoh T., Matsuo E., S a h a t a Y., 1992. Studies on the development of new ornamental Allium through interspecific hybridization. I. Evaluation of commercial ornamental Allium for adaptation to Kagoshima conditions. J. Japan. Soc. Hort. Scien. 61: 659-664.

Friesen N., Fritsch R., B achmann K., 1997. Hybrid origin of some ornamentals of Allium subgenus $\mathrm{Me}$ lanocrommyum verified with GIS and RAPD. Theor. Appl. Gen. 95: 1229-1238.

Frits ch R., Fries en N., 2002. Chapter 1. Evolution, Domestication and Taxonomy. [In:] H. D. Rabinowitch and L. Currach (eds.), Allium Crop Science-Recent Advances: 5-27, ACBI Publishing.

J a b ł oń s k i B., 2003. Metodyka badań obfitości nektarowania kwiatów i oceny miododajności roślin. / Methodology of research on the rate of nectar production and estimation of honey productivity of plants. Wyd. Oddz. Pszczeln., Instytutu Sadownictwa i Kwiaciarstwa, Puławy.

Krzymińska A., 2003. Fenologia i morfologia wybranych gatunków ozdobnych czosnku (Allium L.). / Phenology and morphology of some ornamental species of garlic (Allium L.). Zesz. Problem. Postęp. Nauk Roln. 491:161-168.
Kugler H., 1970. Blütenökologie. Gustav Fischer Verlag, Stuttgart.

Maurizio A., Grafl I., 1969. Das Trachtpflanzenbuch. Ehrentwirth Verlag, München.

Nepi M., Human H., Nicolson S. W., Cresti L., Pac in i E., 2006. Nectary structure and nectar presentation in Aloë castanea and A. greatheadii var. davydna (Asphodelaceae). Plant Syst. Evol., 257: 45-55.

Pacini E., Nepi M., Vesprini J. L., 2003. Nectar biodiversity: a short review. Pl. Syst. Evol. 238: 7-21.

Smets E. F., Ronse Decraene L. P., Caris P., Rud a 11 P. J., 2000. Floral nectaries in monocotyledons: distribution and evolution. [In:] K. L. Wilson D. A., Morrison (eds), Monocots: Systematics and evolution, CRIRO, Melbourne.

Szafer W., Wojtu si a kowa H., 1969. Kwiaty i zwierzęta. Zarys ekologii kwiatów. Państwowe Wydawnictwo Naukowe, Warszawa.

Szk la nowska K., 1982. Wartość pszczelarska i owocowanie niektórych gatunków z rodzaju Allium L. [In:] Studia i Materiały III Seminarium „Zapylanie roślin warzywnych": 216-243, Skierniewice (in Polish).

Vogel S., 1998. Remarkable nectaries: structure ecology, organophyletic perspectives III. Nectar ducts. Flora, 193: 113-131.

Weberling F., 1992. Morphology of flowers and inflorescences. Cambridge Univ. Press, Cambridge.

Weryszko-Chmielewska E., Masierowska M., L a skow sk a H., 2003. Budowa nektarnika acidantery dwubarwnej murielskiej (Acidanthera bicolor var. murielae Perry). / The structure of the nectary of Acidanthera bicolor var. murielae Perry. Ann. Univ. Mariae Curie Skłodowska. Sect. EEE, Hortic. XIII: 123-127.

Weryszko-Chmielewska E., Sawidis T., Piotrowsk a K., 2006. Anatomy and ultrastructure of floral nectaries of Asphodelus aestivus Brot. (Asphodelaceae). Acta Agrobot. 59 (2): 29-42.

Żu raw B., 2007. Owady odwiedzające kwiaty ozdobnych gatunków z rodzaju Allium. [In:] Mat. z 44rd XLIV Nauk. Konf. Pszczel. 24-25 kwietnia 2007, 24-25 March 2007: 103-104, Puławy (in Polish).

Żu raw B., 2008. Nektarowanie kwiatów ozdobnych gatunków czosnku z podrodzaju Allium i Melanocrommyum. [In:] Mat. z XLV Nauk. Konf. Pszczel., 11-12 marca 2008, 11-12 March 2008: 153-154, Puławy. 


\section{Budowa nektarników septalnych i prezentacja nektaru w kwiatach Allium aflatunense B. Fedtsch.}

\section{Streszczenie}

Badano położenie i budowę nektarników septalnych w kwiatach Allium aflatunense B. Fedtsch. Do badań wykorzystano mikroskop świetlny i skaningowy elektronowy. Wykazano, że nektarniki septalne położone są w dolnej części zalążni oraz w gynoforze, na którym osadzona jest zalążnia. Sekrecja nektaru odbywa się za pośrednictwem jednowarstwowej epidermy otaczającej trzy szczeliny nektarnika, a emisja nektaru następuje za pośrednictwem trzech otworów położonych u nasady gynoforu, które stanowią ujścia kanalików połączonych ze szczelinami nektarnika. We wtórnej prezentacji nektaru uczestniczą rozszerzone i zrośnięte nasady nitek pręcikowych oraz listki okwiatu. W kwiatach Allium aflatunense rolę barwnej powabni pełnią liczne purpurowe elementy: listki okwiatu, nitki pręcików, szyjka słupka i szypułka. $\mathrm{Na}$ intensywnie zielonej zalążni występują połyskujące stożkowate wyrostki komórek epidermy, które mogą również funkcjonować jako atraktanty sygnalizacyjne. 
